Documenta \& Instrumenta

ISSN-e: 1697-3798

http://dx.doi.org/10.5209/rev_DOCU.2017.v15.56202

\title{
Leyendas latinas en las cartas de profesión del Císter malagueño (1605-1805): la exégesis bíblica al servicio del ceremonial religioso femenino
}

\author{
Alicia Marchant Rivera ${ }^{1}$
}

Recibido: 7 de febrero de 2017 / Aceptado: 10 de mayo de 2017

Resumen. Se proyecta el análisis sobre la serie de cartas de profesión pertenecientes a la abadía cisterciense de Santa Ana en Málaga (España), y entre ellas las relativas fundamentalmente al período cronológico configurado por los siglos XVII y XVIII; en esta ocasión, no desde la óptica de la Diplomática eclesiástica, sino desde las posibilidades que ofrece el documento escrito para la reconstrucción del ceremonial que rodeó la profesión religiosa femenina, uno de los momentos de la liturgia católica más apreciados y entrañables. Las leyendas latinas que complementan la parte ornamental de algunos de estos documentos albergan remisiones a los textos bíblicos o a los contenidos del Breviario, revitalizando así el sentimiento puro del amor a Dios, marcado por la fórmula del texto escrito de la profesión, que la propia leyenda se encargará de conectar con la vertiente ceremonial que rodea el encuentro de la esposa y Cristo. Localizar, clasificar y comentar las fuentes clásicas y eclesiásticas de donde emanan estos textos, impregnados del más nítido sentimiento místico, será la tarea a abordar en el presente estudio, ayudándonos para ello de otro tipo de fuentes documentales que puedan informar sobre la estabilización de los textos latinos y su uso y empleo en la ceremonia religiosa que da paso a la vida de fe de una fémina en plena Edad Moderna.

Palabras clave. textos latinos; exégesis bíblica; cartas de profesión; ceremonial religioso femenino; siglos XVII y XVIII.

\section{[en] Latin texts in the cistercian profession charts at Málaga (1605-1805): biblical exegesis in the service of the feminine religious ceremonial}

\begin{abstract}
The analysis is projected on the series of profession charts belonging to the cistercian abbey of Santa Ana at Málaga (Spain), those ones mainly related to the chronological period configured by the XVII and XVII th centuries; from the point of the possibilities offered by the document surrounding the female profession, one of the most dear moments of catholic liturgy. Latin legends complementing the ornamental part of some of these documents contain references to biblical text or breviary contents, revitalizing the pure feeling of love to God, where the own legend is responsible for connecting with the ceremonial aspect surrounding the meeting of wife and Christ. Finding, categorizing and commenting on classical and ecclesiastical sources from which emanate these texts, impregnated by the clearest mystic sense, will be the task to address in the present study, referring to another type of documentary sources that can report on latin texts stabilization and use at the religious ceremony, giving way to the faith life of a female in the Modern Age.
\end{abstract}

1 Universidad de Málaga (España)

E-mail: amr@uma.es 
Keywords. Latin texts; biblical exegesis; profession charts; femenine religious ceremonial; XVII th and XVIII th centuries.

Sumario. 1. Preliminares. 2. La abadía de Santa Ana. Breve historia del cenobio y patrimonio documental. 3. Leyendas latinas en las cartas de profesión. 4. Conclusiones.

Cómo citar: A. Marchant Rivera, "Leyendas latinas en las cartas de profesión del Císter malagueño (1605-1805): la exégesis bíblica al servicio del ceremonial religioso femenino", Documenta \& Instrumenta, 15 (2017), pp. 69-89. 


\section{Preliminares}

La profesión religiosa femenina representa el ingreso voluntario en una orden religiosa así como el compromiso de cumplir sus votos ${ }^{2}$. La carta de profesión constituye un documento íntimo y único, individualizado, aunque archivísticamente puedan localizarse encuadernadas $\mathrm{u}$ ordenadas por series, testimonio de la vocación vital de las mujeres que entraron en religión desde el Bajo Medievo hasta el momento actual. Las cartas de profesión no son solo el documento oficial de la vinculación de la profesa a la vida religiosa, sino que en ese formato del documento decorado está plasmado el amor y la ilusión con que la novicia se preparaba para su profesión. Es un documento personal escrito para Dios, que es el destinatario de esa acción ${ }^{3}$.

El estudio que se presenta pretende proyectar un análisis sobre la serie de cartas de profesión pertenecientes a la Abadía cisterciense de Santa Ana en Málaga, y entre ellas las relativas fundamentalmente al periodo cronológico configurado por los siglos XVII y XVIII; en esta ocasión, no desde la óptica de la Diplomática eclesiástica, labor que se ha abordado en anteriores trabajos ${ }^{4}$, sino desde las posibilidades que ofrece el documento escrito para la reconstrucción del ceremonial que rodeó la profesión religiosa femenina, uno de los momentos de la liturgia católica más apreciados y entrañables. Las leyendas que pueblan la parte ornamental de algunos de estos documentos insertan textos latinos que nos remiten a los textos bíblicos o a la consuetudo del Breviario, revitalizando así el sentimiento puro del amor a Dios, marcado por la fórmula del texto escrito, que la propia leyenda se encargará de conectar con la vertiente ceremonial que rodea el encuentro de la esposa y Cristo.

Localizar pues las fuentes clásicas y eclesiásticas de donde emanan estos versículos, sentencias, poemas y recuerdos, impregnados del más nítido sentimiento místico, será la tarea a abordar en el presente estudio, ayudándonos para ello de otro tipo de fuentes documentales colaterales que puedan arrojar luz y origen sobre la estabilización de los textos latinos y su uso y empleo en la ceremonia religiosa que da paso a la vida de fe de una fémina en plena Edad Moderna.

\section{La abadía de Santa Ana. Breve historia del cenobio y patrimonio documen- tal}

Sus antecedentes se remontan a una fundación del obispo García de Haro, quien en 1593 creó una casa de arrepentidas con el nombre de Jesús María. Esta primitiva

2 Este trabajo se incardina en el Proyecto de Investigación "Poder, identidades e imágenes de ciudad: música y libros de ceremonial religioso en la España meridional (siglos XVI-XIX)” (MINECO HAR2015-65912-P).

3 J. C. VIZUETE MENDOZA y J. CAMPOS Y FERNÁNDEZ DE SEVILLA, OSA, Iluminaciones. La profesión religiosa y sus signos, San Lorenzo del Escorial, 2013, p. 9.

4 A. MARCHANT RIVERA, "Aproximación a la diplomática eclesiástica a través de la documentación conventual: las cartas de profesión de la abadía cisterciense de Santa Ana en Málaga”, en Boletín de la Sociedad española de Ciencias y Técnicas Historiográficas, 3 (2005), pp. 319-330.

A. MARCHANT RIVERA, "Iter escriturario y ceremonial de la profesión religiosa femenina", en Escritura y Sociedad: el clero, Granada, 2017. 
institución recibe el impulso definitivo gracias a la labor del obispo Juan Alonso Moscoso, que en 1604 se decantó por la orden del Císter y mandó traer las reglas y constituciones del Convento de Recoletas Bernardas de Valladolid ${ }^{5}$. En el año 1878 se reedificaron la Iglesia y el Monasterio actual sobre el mismo solar de antaño. Hasta que finalmente, en la década de los 80 del siglo XX se efectuaron remodelaciones interiores en el conjunto. A comienzos del presente siglo, las nuevas obras prepararon el espacio para el traslado del Museo de arte sacro diocesano anejo a la Abadía, hasta que en el año 2009 se produjo la disolución de la Comunidad y su traslado y fusión con las religiosas del Convento de la Anunciación de Santo Domingo de la Calzada en La Rioja.

El Archivo de la Abadía de Santa Ana contuvo un patrimonio documental que abarca una cronología comprendida entre el año 1604 y el año 2009, y que contiene en su haber: Libros de Fundaciones, Padrones, Libros de Visitas Canónicas, Libro Mudéjar o Libro de Actas de toma de hábito y profesión, Libro inventario de la ropería, Libro inventario de la secretaría, Libros de cuentas, Libros conmemorativos y las Cartas de profesión propiamente dichas ${ }^{6}$. Esta últimas constituyen un conjunto de 205 cartas de profesión cuya horquilla cronológica se corresponde con la amplitud del archivo y sobre las cuales se ha publicado un catálogo ${ }^{7}$ y se han proyectado diversos estudios artísticos ${ }^{8}$, de historia eclesiástica ${ }^{9}$ y de corte lingüístico $^{10}$.

\section{Leyendas latinas en las cartas de profesión}

A modo de referencia genérica - para incardinar el rito de la profesión que refrenda la serie de cartas que se van a examinar a continuación-, habría que indicar que en los ceremoniales benedictinos, seguidos por la Orden del Císter, se señala que la profesión se hará en el ofertorio, durante la celebración de la misa: "Ordenamos que se guarde la costumbre antigua que la profesión se haya de dar en la iglesia, al ofertorio de la misa mayor". Es decir, después del Credo, antes del ofertorio: "Postea sub Evangelio seu Credo, si cantetur misase illius in qua suscipiendus est". Igualmente, en el ceremonial de la Congregación de España se establecerá que la profesión deberá realizarse "en día de fiesta, a la misa mayor" ${ }^{11}$. Será pues a este

5 M. CARMEN GÓMEZ GARCÍA, "La Abadía de Santa Ana del Císter en Málaga", en La clausura femenina en España, Madrid, 2004, pp. 741-760.

M. C. GÓMEZ GARCÍA, "Orígenes y extinción del convento del Císter en Málaga”, en, La clausura femenina en el mundo hispánico: una fidelidad secular, Madrid, 2011, pp. 713-724.

6 Actualmente y, tras la disolución de la comunidad, todos estos fondos se custodian en el Archivo Municipal de la ciudad.

7 A. MARCHANT RIVERA, Las religiosas del Císter malagueño. Catálogo de las cartas de profesión de la Abadía de Santa Ana, Málaga, 2010.

$8 \quad$ R. CAMACHO MARTÍNEZ, "Las cartas de profesión del convento del Císter de Málaga: un documento entre la devoción, el derecho y el arte", en La clausura femenina en España, vol. 2, Madrid, 2004.

M. C. GÓMEZ GARCÍA y J. VERGARA “El archivo de la Abadía de Santa Ana del Císter de Málaga: las cartas de profesión ¿Documentos biográficos o artísticos?”, Memoria ecclesiae, 30 (2007), pp. 239-250.

9 A. MARCHANT RIVERA, “Aproximación a la diplomática eclesiástica ...”, pp. 319-330.

10 P. CARRASCO CANTOS, Las cartas de profesión. Análisis lingüistico, http://hdl.handle.net/10630/10562

11 J. C. VIZUETE MENDOZA y J. CAMPOS Y FERNÁNDEZ DE SEVILLA, OSA, Iluminaciones..., p. 107. 
momento de la celebración litúrgica al que debamos vincular los textos bíblicos de los que se va a dar cuenta a continuación.

De la serie de cartas analizadas en esta horquilla cronológica (1605-1805), de un total de 135 cartas, solo 14 incluyen junto al texto de la profesión $-\mathrm{y}$ los dibujos, alegorías y decoraciones - textos en latín. En total se trata de 12 textos latinos diversos, ya que algunas cartas de profesión repiten los motivos bíblicos o litúrgicos insertos en algún ejemplar inmediatamente anterior. A continuación se va a proceder a identificarlos textualmente (precedidos de la fecha de profesión de la religiosa y de la numeración de la carta en el catálogo ${ }^{12}$ ), localizar la fuente latina de la que emanan, comentándola brevemente, y a proporcionar su traducción al castellano ${ }^{13}$. Seguida esta labor de la inserción de la imagen de la carta de profesión en cuestión, lo que nos permitirá ubicar el texto latino en su contexto documental.

1) Carta de profesión de Sor Juana de la Madre de Dios (12-7-1649; 23).

Texto leyenda: "Mulier timens Dominum", "Ipsa laudabitur prober". Aves que sostienen cintas en el pico con las leyendas.

Fuente: Proverbios 31:30, "Fallax gratia et vana est pulchritudo. Mulier timens Dominum ipsa laudabitur".

Traducción: Engañosa es la gracia, y vana la hermosura; La mujer que teme a Jehová, ésa será alabada.

Los Proverbios, en la tradición bíblica del cristianismo, es un libro del Antiguo Testamento que se clasifica entre los Libros Sapienciales. Está compuesto por extensas colecciones de máximas o sentencias de contenido religioso o moral y se ubica en la Biblia entre el libro de los Salmos y el Eclesiastés. Según los estudios de Whybray, que han sido generalmente aceptados por los demás exégetas, se puede dividir el libro de los Proverbios en ocho secciones: en la octava sección se encuentra incardinado el pasaje 31, 10-31, donde se ubica nuestra primera leyenda, en el contexto de las alabanzas a la mujer fuerte. Se trata pues del elogio de la mujer virtuosa, lo que redunda en el dechado de cualidades que ha de abanderar la religiosa profesa como esposa de Cristo $^{14}$. Desposorio al que también aluden los textos más íntimos de religiosas universales como Santa Teresa de Jesús, quien en el Libro de la vida profiere: "No sé cómo he de pasar de aquí, cuando me acuerdo la manera de mi profesión (5-11-1537) y la gran determinación y contento con que la hice y el desposorio que hice con Vos" ${ }^{\text {". }}$. Esta misma leyenda latina se repite en las cartas de profesión de otras religiosas del Císter malagueño, como Sor María de San Luis (4-7-1670; 36) o Sor Isabel María de San Miguel, esta última con Santa Escolástica, hermana de San Benito (santo de la Orden cisterciense), en el escudo (1-5-1672; 40).

2) Carta de profesión de Sor Catalina Antonia de San Blas (21-6-1671; 38).

Textos leyendas: "Arma militiae nostrae" (1) y "Veni sponsa Cristi" (2). Escudo del Císter flanqueado por aves que sostienen bandas con leyenda en el pico.

\footnotetext{
12 A. MARCHANT RIVERA, Las religiosas del Císter malagueño..., Málaga, 2010.

13 La versión bíblica empleada para el cotejo de las leyendas ha sido La Biblia Vulgata latina traducida al español y anotada por el Ilmo. Señor Don Felipe Scio de San Miguel, París, 1857. Las traducciones de los textos latinos son responsabilidad íntegra de la autora de este estudio.

14 R. WHYBRAY, "Some literary Problems in Proverbs I-IX”, VT 16 (1966), pp. 482-496.

15 J. C. VIZUETE MENDOZA Y J. CAMPOS Y FERNÁNDEZ DE SEVILLA, Iluminaciones..., p. 58.
} 
Fuente 1: II Corintios 10:4, "Nam arma militiæ nostræ non carnalia sunt, sed potentia Deo ad destructionem munitionum".

Traducción 1: Porque las armas de nuestra milicia no son carnales, sino poderosas en Dios para la destrucción de fortalezas.

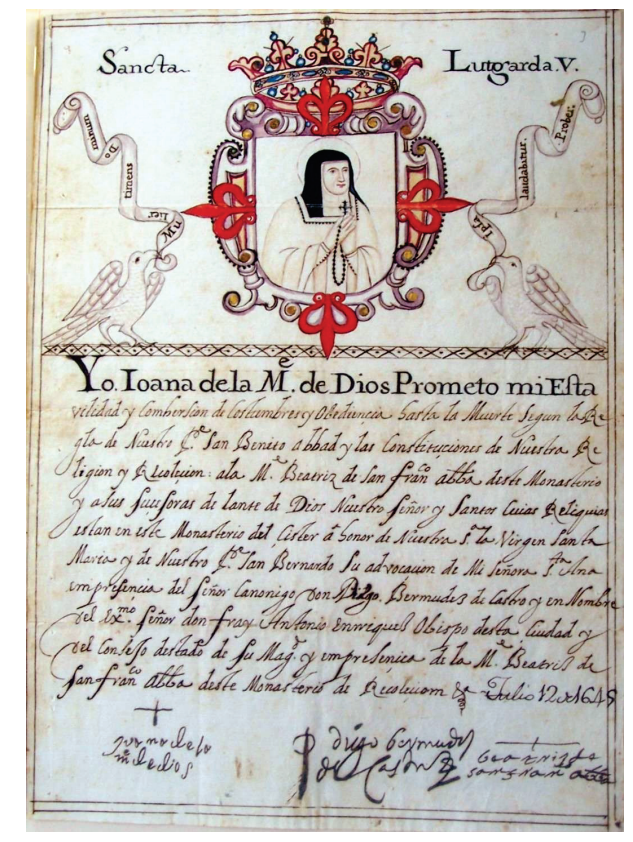

La segunda epístola a los Corintios es un escrito que pertenece al Nuevo Testamento, la parte más reciente de la Biblia. El conjunto de documentos que forman el Nuevo Testamento se escribieron en el siglo primero. Es una carta escrita por Pablo de Tarso a la comunidad cristiana en Corinto. Poco después de escribir su primera carta a los Corintios, Pablo salió de Éfeso para llegar a Macedonia. Escrita por el año 57, tiene como finalidad la apologética del ministerio apostólico de Pablo. Tras observar el fruto de su primera epístola con la creación de nuevas comunidades cristianas, la segunda carta se dirige nuevamente a estos conversos, a los que se trata con gran cariño: «Vosotros sois nuestra carta, escrita en nuestros corazones». Así las armas que tenemos que son "poderosas en Dios" incluyen gracias tales como "mansedumbre," "gentileza," "paciencia," y "humildad", cualidades que aparecen relacionadas con las virtudes del catecismo católico, y que precisamente cobran protagonismo en otra carta posterior de la serie ${ }^{16}$.

Fuente 2: "Veni, sponsa Christi, accipe coronam, quam tibi Dominus praeparavit in aeternum". La Antífona "Veni Sponsa Christi", del Breviario, pertenece al Oficio de Laudes del Domingo de Adviento, se trata concretamente de la antífona del Magnificat Se cantaba en la ceremonia de profesión mientras que el sacerdote bendecía el velo y el hábito ${ }^{17}$.

16 B. D. EHRMAN, Simón Pedro, Pablo de Tarso y María Magdalena, Barcelona, 2007.

17 En síntesis, el Breviario recoge las oraciones, lecturas bíblicas y salmos que deben ser rezados o recitados en las diferentes horas del día y según el periodo del año. Las primeras ediciones de breviarios fueron de finales 
Traducción 2: Ven, esposa de Cristo, recibe la corona que Dios te ha preparado para la eternidad.

Palabras que también aparecen refrendadas por los propios testimonios que las religiosas registraban del recuerdo del día de su profesión: "Vinieron a mi entrada mi padre y todos mis hermanos, y en tanto que llegaba el día asignado, que fue el 25 de julio del año 1748, y no veía la hora de entrar porque me tenían sin vida. Todo se les iba en llorar y en mostrarme tal sentimiento que ni me hablaban (...) El mundo lo dejé con todo mi corazón. Entrando por las puertas de la clausura me pareció que entraba por las del cielo oyendo la antífona Veni sponsa Christo" ${ }^{18}$.

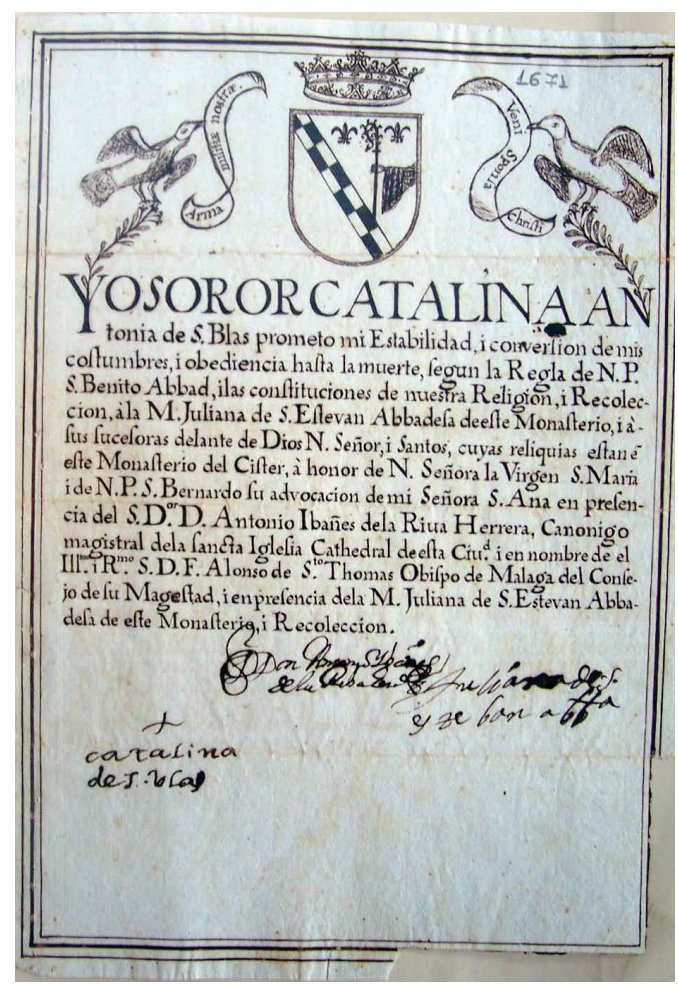

3) Carta de profesión de Sor Ana Marcela de Jesús María (9-2-1673; 43). La paloma del Espíritu Santo suspendida bajo una corona junto a tres leyendas ("Iesu, corona virginum"; "Haec est virgo sapiens"; "Accipe coronam quam tibi Deus preparavit"), de las cuales solo resaltamos la medial por pertenecer a una tradición exegética diferente a lo ya explicado.

Texto leyenda: "Hec est virgo sapiens... (quam Dominus vigilantem invenit)".

Fuente: Antífona del Evangelio de S. Mateo 25: 1-13.

del siglo XI y estaban destinadas a facilitar el transporte de los libros de horas a los clérigos. Con el tiempo, el breviario pasó de ser una obra que reunía y abarcaba otras, para convertirse en libro litúrgico por excelencia, al que se aplicaron normas canónicas de uso y contenido. Vid. Ilustración apologética al breviario, misal y ritual cisterciense de la congregación de San Bernardo, Madrid, 1783.

18 J. C. VIZUETE Y MENDOZA Y J. CAMPOS Y FERNÁNDEZ DE SEVILLA, Iluminaciones, p. 78 (testimonio de Sor María Marcela Soria, Méjico 1719-Querétano?). 
Traducción: Esta es la virgen prudente, a quien el Señor encontró en vela (y que, al llegar el Señor, entró con él a la boda).

La mejor exégesis de este texto bíblico es la que el propio Jesucristo ofrece al final de la parábola: "Velad, pues, porque no sabéis el día ni la hora en la que el Hijo del Hombre ha de venir". La idea de virgen y esposa, que nuevamente se reitera, es un texto más que apropiado para la profesión religiosa femenina, según lo explicado con anterioridad. Lo más probable es que evangelios como este se leyeran en la misa mayor en la que se llevaba a cabo la profesión de la religiosa, por su conveniencia temática. Así lo sugieren rituales de profesión donde se especifica: "En la elección de las diferentes perícopas bíblicas o de los textos litúrgicos que aquí se presentan, "ad libitum" del celebrante,(...) nuestros religiosos se adhieran a las formas más puras de la liturgia y las sigan"19. Si las lecturas de la misa mayor se escogían a voluntad del celebrante, no es raro que este tuviera sensibilidad para promocionar los textos bíblicos con mayor vínculo semántico, o aquellos otros a los que la orden tenía especial afección por tradición de sus patronos o fundadores.

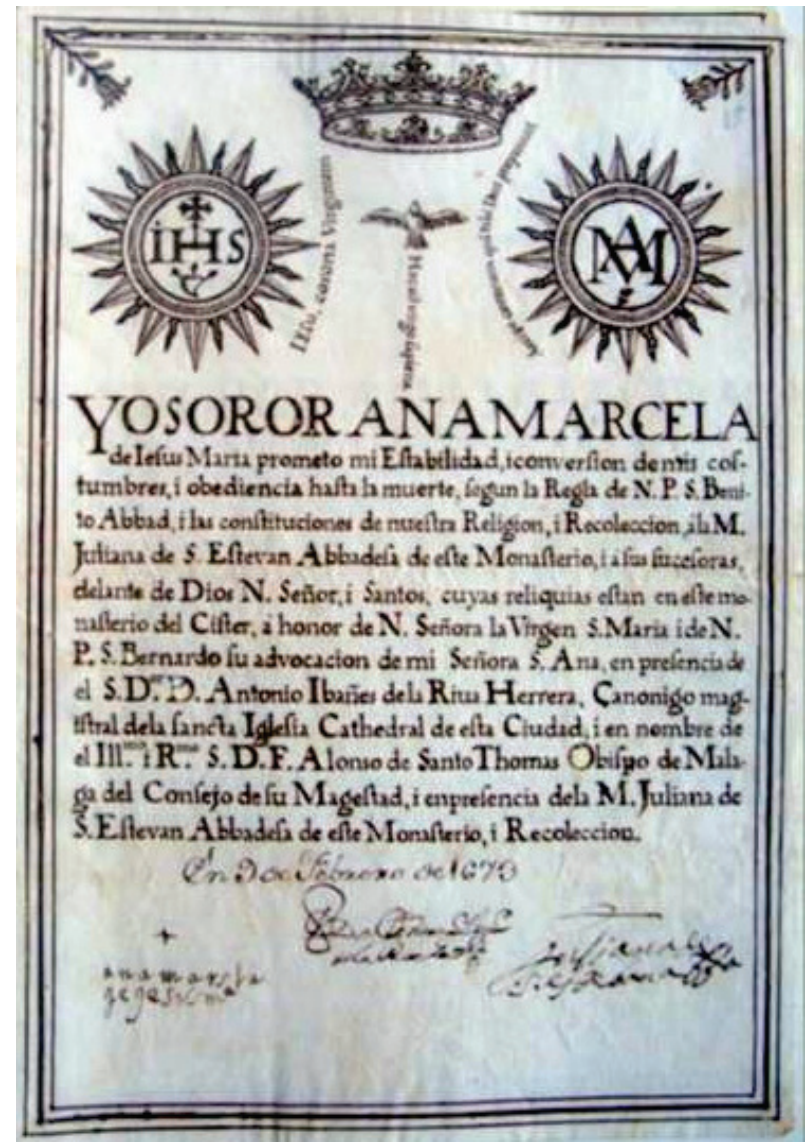

19 Ritual de la profesión religiosa de los clérigos regulares (Teatinos), artículo XVII, p. 6. https://issuu.com/padresteatinos/docs/ritual_profesion-2/13 
4) Carta de profesión de Sor María Bernarda de San José (6- 1-1679; 47) Corazón rojo con la leyenda inserta.

Texto leyenda: "Mihi et ego illi Dilectus meus".

Fuente: Cantar de los Cantares 2, 16-17, "Mihi et ego illi Dilectus meus, (qui pascitur inter lilia donec adspiret dies inclinentur umbrae)".

Traducción: "Mi amado para mí y yo para él, que se apacienta entre azucenas, (hasta que expire el día y caigan las sombras)".

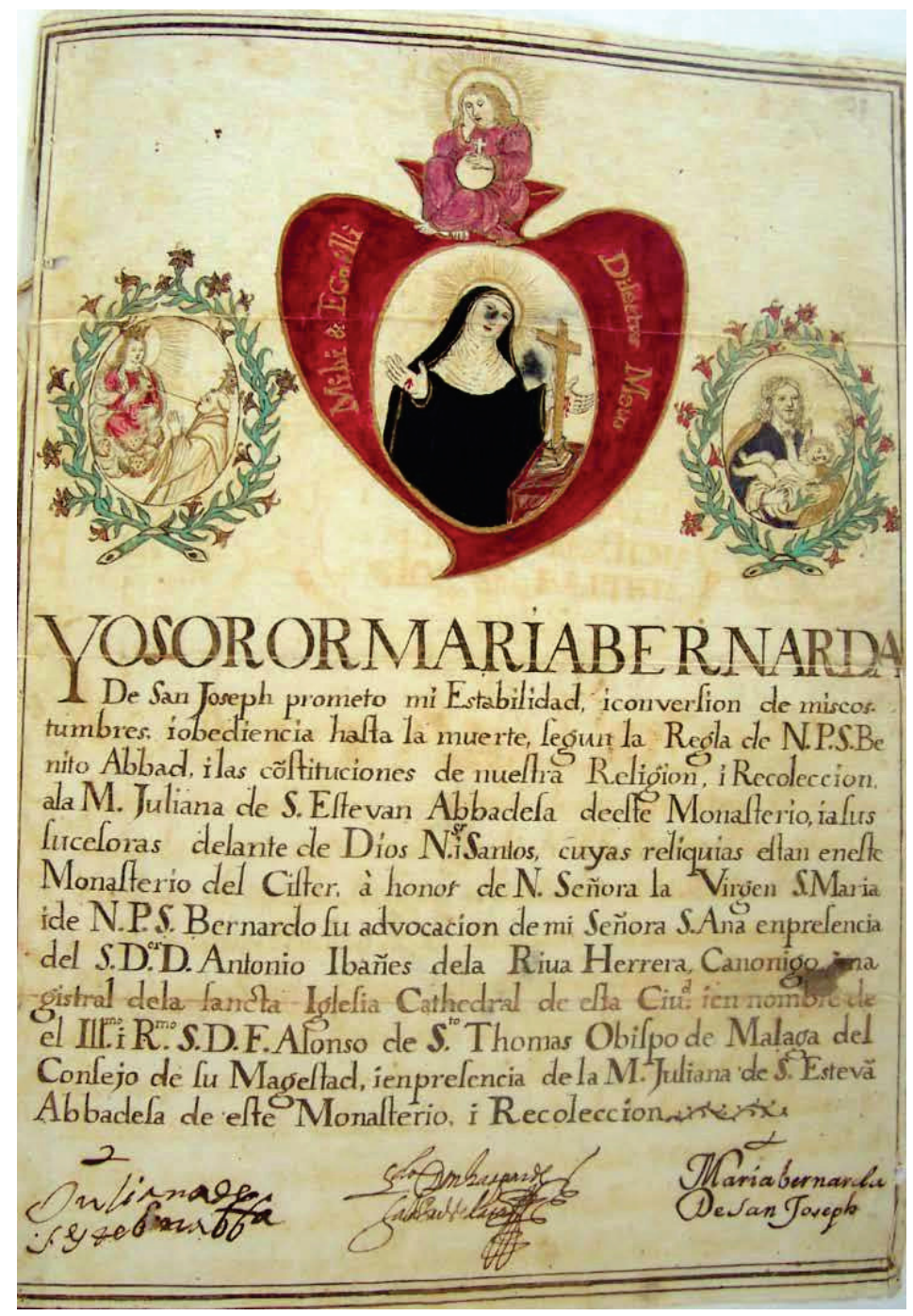

A primera vista, el Cantar de los Cantares $^{20}$ se estructura como un poema de amor conyugal a voces o cantos alternos, un joven pastor y una sulamita, con lo

20 La introducción al Cantar de los Cantares señala a Salomón como autor del libro, y así lo han considerado tradicionalmente las religiones judía y cristiana. Sin embargo, esta atribución supone que la obra debió componerse en el siglo X a.C., lo cual se considera inverosímil, pues, como señala el arqueólogo Israel Finkels- 
que de nuevo se pone de manifiesto el acento musical de la profesión religiosa femenina. De hecho, los Libros de Reglas y Constituciones relatan pasajes semejantes a este, que sitúan la primera fase del rito de la profesión vinculada al canto: "La profesión tenía lugar en la iglesia, estando el que la recibiera en ella y las monjas, en el coro. Una vez que la novicia se encontrara en su presencia, el sacerdote le dirigía una plática ponderándole qué era la profesión y los votos que iba a emitir. Luego la despojarían de las vestiduras del noviciado y el sacerdote bendeciría el velo y el hábito de profesa, mientras la comunidad canta la antífona Veni Sponsa Christi" $^{21}$. Una de las claves del Cantar de los Cantares es la forma descriptiva y sensual con la que se desarrollan todas las situaciones, utilizando la metáfora a través del mundo de la naturaleza, para relacionarlo con los enamorados y el amor profundo entre ambos. A este interés responde la segunda parte de la leyenda latina, omitida en la carta de profesión de Sor María Bernarda y recuperada en la fuente ("qui pascitur inter lilia donec adspiret dies inclinentur umbrae"; "que se apacienta entre azucenas, hasta que expire el día y caigan las sombras"). Por su parte Bernardo de Claraval, santo venerado por la orden cisterciense, encontró en la esencia de este libro bíblico una forma nueva de expresar el amor hacia Dios, razón que avala la elección, según lo expuesto en la explicación de la carta anterior, de los textos de este libro bíblico para el rito de la profesión. De hecho, San Bernardo cita en sus obras este libro bíblico un total de 241 veces, lo que indica que era un texto con el que se identificaba ${ }^{22}$.

5) Carta de profesión de Sor Teresa de Santa Escolástica (8-9-1679; 48). De nuevo se reitera el motivo de aves que sostienen en el pico bandas con leyendas, flanqueando un escudo central con la imagen de Teresa de Jesús.

Texto leyenda: "Veni de Libano, veni, Coronaveris de capite..." y "Veni de Libano, sponsa mea".

Fuente: Cantar de los Cantares 4, 8, "Veni de Libano, sponsa, veni de Libano, veni, coronaberis de capite Amana, de vertice Sanir et Hermon, de cubilibus leonum, de montibus pardorum".

Traducción: "Ven desde el Líbano, esposa mía, ven desde el Líbano, ven: serás coronada de la cumbre de Amana, desde la cumbre de Senir y de Hermón. Desde las guaridas de los leones, desde los montes de los leopardos".

En esta ocasión la religiosa toma el nombre de Teresa, de ahí la alegoría del escudo, nombre al que añade la advocación de Santa Escolástica, hermana este última de San Benito de Nursia, santo muy venerado también por la orden cisterciense. No en vano San Bernardo de Claraval tenía una gran devoción a Benito de Nursia y a su única obra, la Regula monasteriorum. Esta obra era la maestra de su corazón y de su intelecto, y estaba convencido que, como la Biblia, era un libro directamente inspirado por Dios ${ }^{23}$. Como se ha podido comprobar, en la leyenda latina de esta

tein, los cinco primeros libros de la Biblia no se compusieron hasta el siglo VII a.C. El hebreo empleado en el texto es, además, obviamente tardío y contiene algunos arameísmos e incluso influencias del griego. Por todos esos motivos filológicos y por la simbología de la obra, Ricciotti sitúa la redacción en el siglo IV a.C. Vid. E. FERNÁNDEZ TEJERO, El cantar más bello. El Cantar de los Cantares de Salomón, Madrid, 2007.

21 Reglas y Constituciones del monasterio de religiosas de la Purísima Concepción, Mercedarias descalzas de la villa de Madrid...Madrid, 1766, cap. XLIV, pp. 186-213.

22 G. DÍAZ RAMOS, Obras completas de san Bernardo, Madrid, 1953, p. 56.

23 D. J. LECLERCQ, “San Bernardo y la regla de San Benito”, Cuadernos monásticos, 94 (1990), pp. 307-323. 
carta de profesión solo figuran retazos de la fuente bíblica completa, detalle textual refrendo del ritual sobre el que más adelante volveremos.

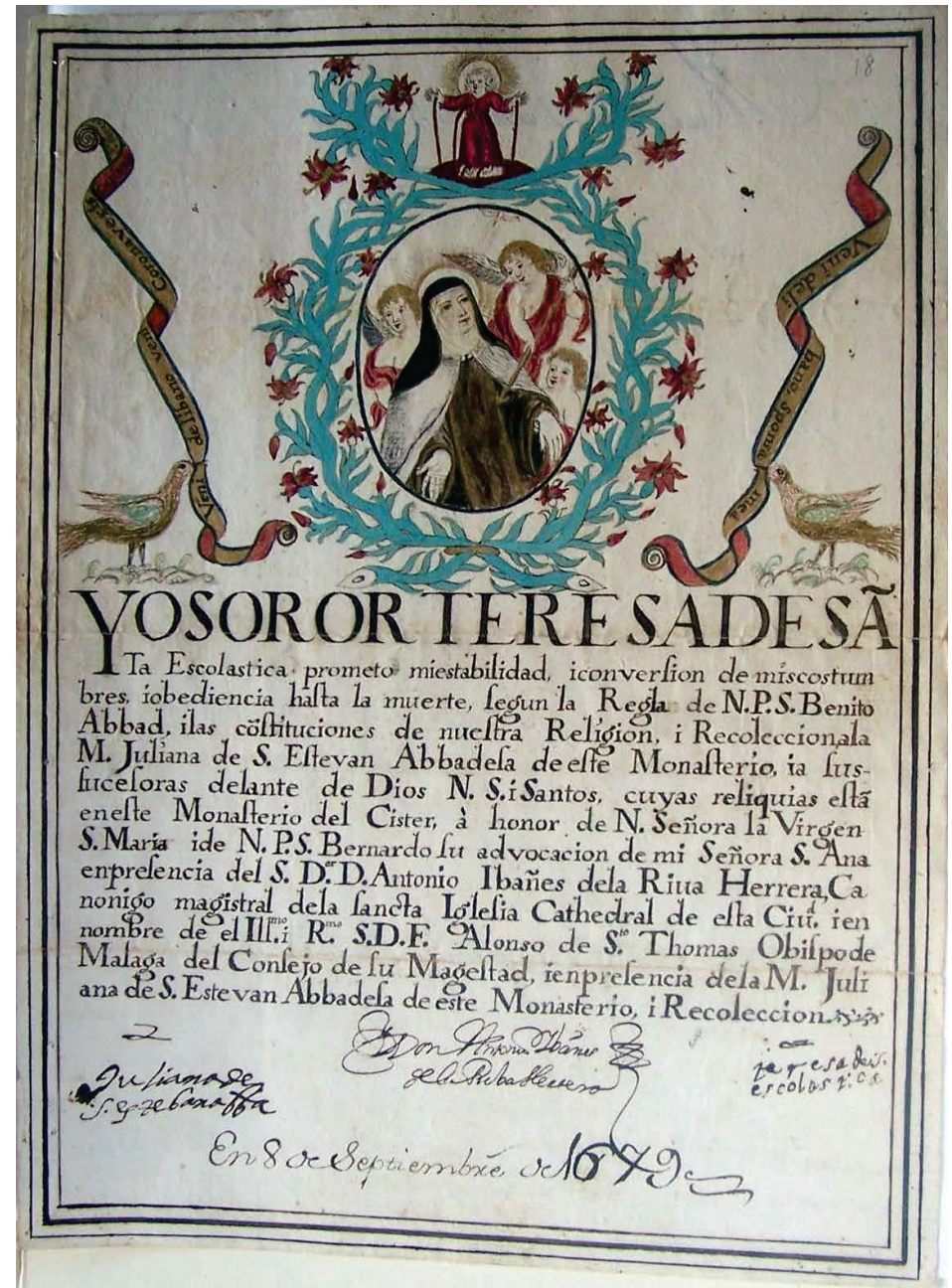

6) Carta de profesión de Sor Rosa de Santa María (16-10-1686; 52). Una representación pictórica de la novicia aparece flanqueada por escudos con San Benito y San Bernardo. Al escudo central con la representación de la novicia circunda la leyenda.

Texto leyenda: "Quasi Rosa plantata super rivos aquarum Eccle. C. 39".

Fuente: Libro del Eclesiástico, cap. 39.vers.17, "(Obaudite me, divini fructus, et) quasi rosa plantata super rivos aquarum (fructificate)".

Traducción: Oídme, descendencia divina, y reverdeced como la rosa plantada junto a arroyos de aguas.

El objeto del Eclesiástico es enseñar la sabiduría, es decir, las reglas para hallar la felicidad en la vida de amistad con Dios. De ahí que se le ha llamado "Tratado de ética a lo divino". Para ilustrar su doctrina, recorre finalmente el autor en los capítulos 44-50 la historia del pueblo escogido, presentándonos con elogio los va- 
rones sabios y justos desde Abraham hasta Simón, hijo de Onías. Termina con una oración y una maravillosa exhortación para que todos aprendan y aprovechen de la sabiduría que a todos se brinda gratuitamente para saciar la sed del corazón.

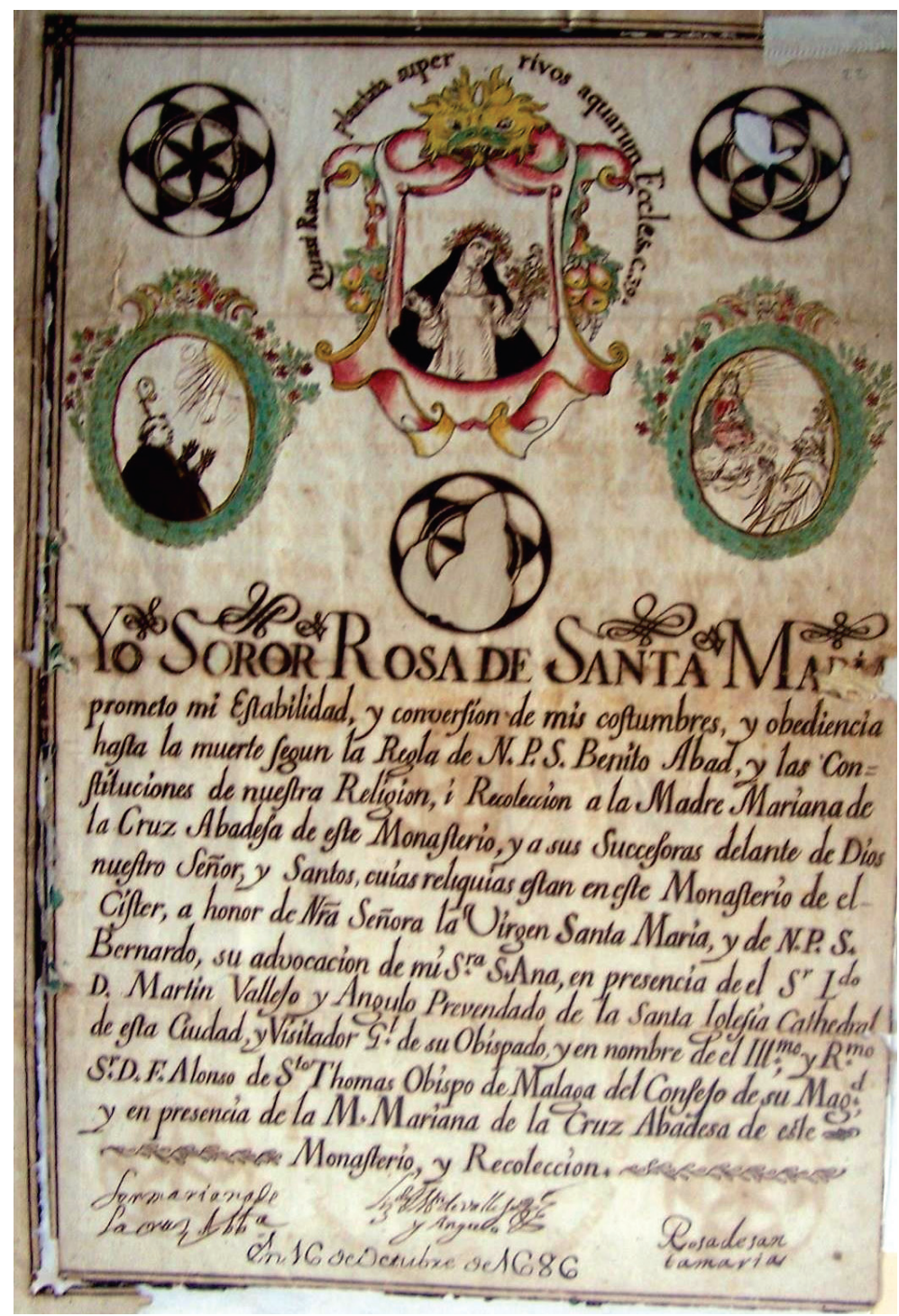

Según las diez secciones que propone Peters en el texto, la novena $(39,16-43$, 37) se centra en la alabanza de la Divina Providencia, la vida humana, sus penas y alegrías; el castigo de los impíos, la verdadera y falsa vergüenza y el himno a Dios Creador $^{24}$. En esta apartado está incluida la leyenda objeto de nuestro estudio que,

24 El nombre de este libro, El Eclesiástico, es debido al constante uso que de él se hacía en la Iglesia, especialmente en la instrucción del pueblo y de los catecúmenos que iban a ser bautizados. El nombre de Libro de Je- 
en su referencia a los elementos naturales, entra en conexión con las metáforas empleadas en el Cantar de los Cantares, tan del gusto de Bernardo de Claraval y, por extensión, de la comunidad cisterciense.

7) Carta de profesión de Sor Ana Bernarda de San Juan (30-1-1689; 54). Escudo de Juan el Bautista flanqueado por los santos Benito y Bernardo.

Texto leyenda: "Inter natos mulierum non surrexit maior Ioanne Baptista"

Fuente: Evangelio de San Mateo 11,11.

Traducción: "Entre los nacidos de mujer, no surgió nadie mayor que Juan el Bautista"

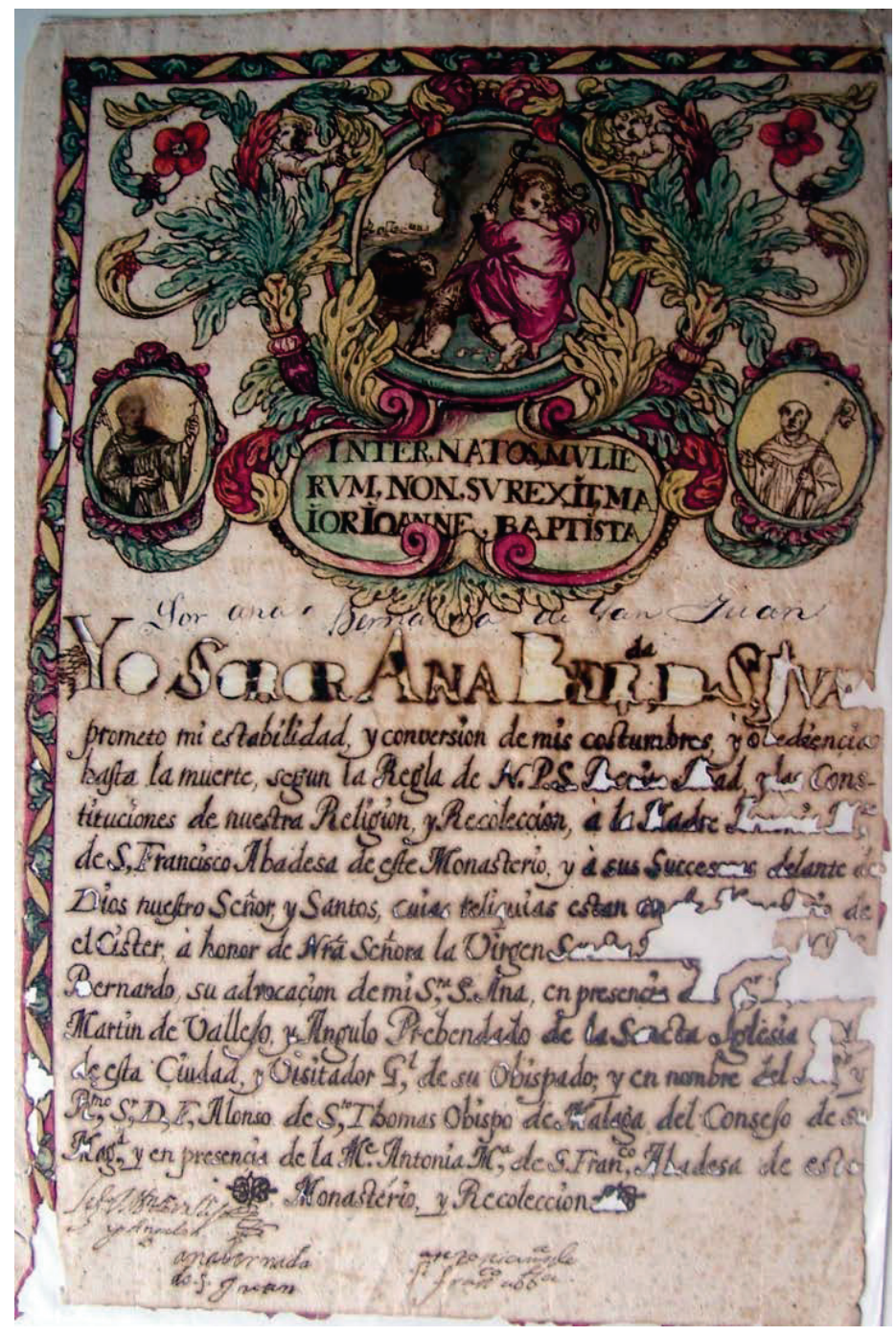

sús, hijo de Sirac, o Sabiduría de Sirac, le viene de su autor Jesús (Josué), descendiente de un cierto Sirac que vivía en Palestina al comienzo del siglo II a. C. El libro fue, pues, escrito por los años 200-170 a. C.

J. C. GIMENO GRANERO, "El texto del libro del Eclesiástico", en Escritos del Vedat, 33 (2003), pp. 49-77.

J. CARLOS GIMENO GRANERO, "El Libro del Eclesiástico: la sabiduría religiosa", en Escritos del Vedat, 35 (2005), pp. 219-284. 
La exégesis de esta elección de texto bíblico podemos vincularla al Sermón 66, 2-5, de San Agustín, que inserta el comentario a Mt 11, 2-11. No en vano los Padres de la Iglesia que más siguió Bernardo de Claraval, los que entonces se consideraban los maestros más autorizados de la Iglesia, fueron San Ambrosio y San Agustín, a quienes San Bernardo denominó las dos columnas de la Iglesia apostillando en su Tratado sobre el bautismo que difícilmente se apartaría de su parecer. Según el santo de Hipona, entre los nacidos de mujer no surgió nadie mayor que Juan Bautista, pero el que es menor, en el reino de los cielos es mayor que él: "recomendó ese reino que hemos de desear; presentó la ciudad cuyos ciudadanos debemos desear ser. ¿Qué ciudadanos hay allí? ¡Qué grandes ciudadanos! El menor de ellos es mayor que Juan. ¿Qué Juan? Aquel mayor que el cual no surgió nadie entre los nacidos de mujer" 25 .

8) Carta de profesión de Sor Catalina de San Bernardo (15-10-1693; 58). Escudo central con la representación gráfica de una profesa que sostiene una pluma en la mano y escribe en un libro "Soy de Jesús", al que rodea la leyenda.

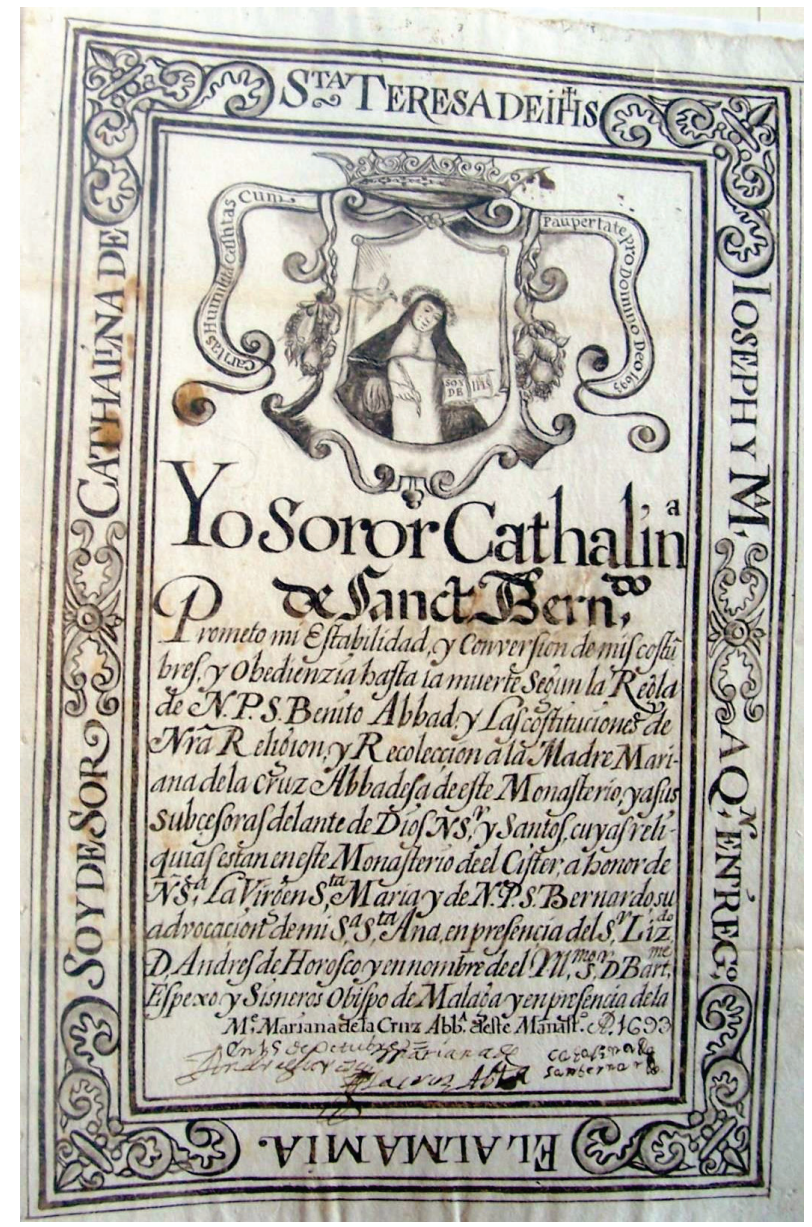

25 Obras completas de San Agustín: Sermones, Madrid, 1984. 
Texto Leyenda: "Caritas Humilitas Castitas cum paupertate pro Domino Deo 1693”.

Fuente: Relación con los votos monásticos y, por extensión, con las siete virtudes del catecismo católico cristiano (Humildad, Generosidad, Castidad, Paciencia, Templanza, Caridad y Diligencia).

Traducción: "Caridad, Humildad, Castidad, junto a la pobreza en favor de Dios, el Señor". A lo que se añade el año de la profesión.

Los votos monásticos son las promesas que han distinguido desde siglos a un religioso de un seglar dentro de la iglesia católica. Mediante ellos se pretende acceder a una vía espiritual a la salvación a través de la renuncia de placeres terrenales. Por regla general, los votos son tres: pobreza, obediencia y castidad. Constituyen un reflejo de la vida de Jesucristo, según los consejos evangélicos. La profesión religiosa es una obligación que se autoimpone, en nuestro caso, la religiosa para cumplir esos votos.

Entre los benedictinos y cartujos los votos se consideran comprendidos en la conversio morum o conversión de costumbres: promittat de stabilitate sua et conversatione morum suorum et oboedientia. Es el capítulo 58 de la Regla de San Benito De disciplina suscipiendorum fratrum, titulado en la versión castellana "El modo de recibir a los hermanos" ${ }^{26}$. En la serie de cartas que venimos analizando los votos se condensan en el sintagma que sucede a la intitulatio: "Prometo mi estabilidad y conversión de mis costumbres y obediencia...".

9) Carta de profesión de Sor María Catalina de Santa Rosalía (12-5-1725; 76).

Escudos con leyendas flanquean una estampa con Santa Gertrudis.

Texto leyenda: "Mater Dolorosa, ora pro me" y "S. P. Benedicte, ora pro me"

Fuente: Relación con el rezo del Rosario y las letanías.

Traducción: "Madre Dolorosa, reza por mí" y "Padre San Benito, reza por mí".

El texto entra en conexión directa con el universo de los rosarios públicos o callejeros, que surgieron en Sevilla en 1690 y se extendieron muy pronto por España y sus colonias americanas. Eran cortejos precedidos por una cruz, que contaban con faroles de mano y faroles de asta para alumbrar los coros, y que estaban presididos por la insignia mariana denominada Simpecado. Al principio eran masculinos, pero ya en el primer tercio del XVIII aparecieron los primeros rosarios de mujeres que salían los festivos por la tarde ${ }^{27}$. El rezo del rosario, y fundamentalmente la recitación de sus letanías aparejadas, desempeña un papel relevante en el ceremonial de la profesión religiosa femenina, en el que la conclusión del rezo de las letanías por parte de la Comunidad daba paso a la lectura del texto de la profesión recitado por la profesa: "Luego por la ventanilla del comulgatorio la vestirá, ayudado por la Maestra de novicias. Tras ponerle el velo le colocará una corona de flores o una palma o un ramo de laurel en las manos; luego le dará una vela encendida y, tras las oraciones del sacerdote, la que profesa se postrará en el suelo mientras la Co-

26 La Regla de San Benito, Pamplona, 1792.

27 C. J. ROMERO MENSAQUE, "La predicación dominicana del Rosario. El Rosario de la aurora de Zafra en el siglo XVIII”, Revista de Humanidades [en línea], 27 (2016), artículo 8. Disponible en http://www. revistadehumanidades.com/articulos/104-la-predicacion-dominicana-del-rosario-el-rosario-de-la-aurora-de-zafra-enel-siglo-xviii [Consulta: Martes, 31 de Enero de 2017]. 
munidad reza las letanías. Concluidas estas, pronunciará su profesión, pues en pie, leyéndola de libro donde la habrá escrito con su propia mano ${ }^{28 ،}$.

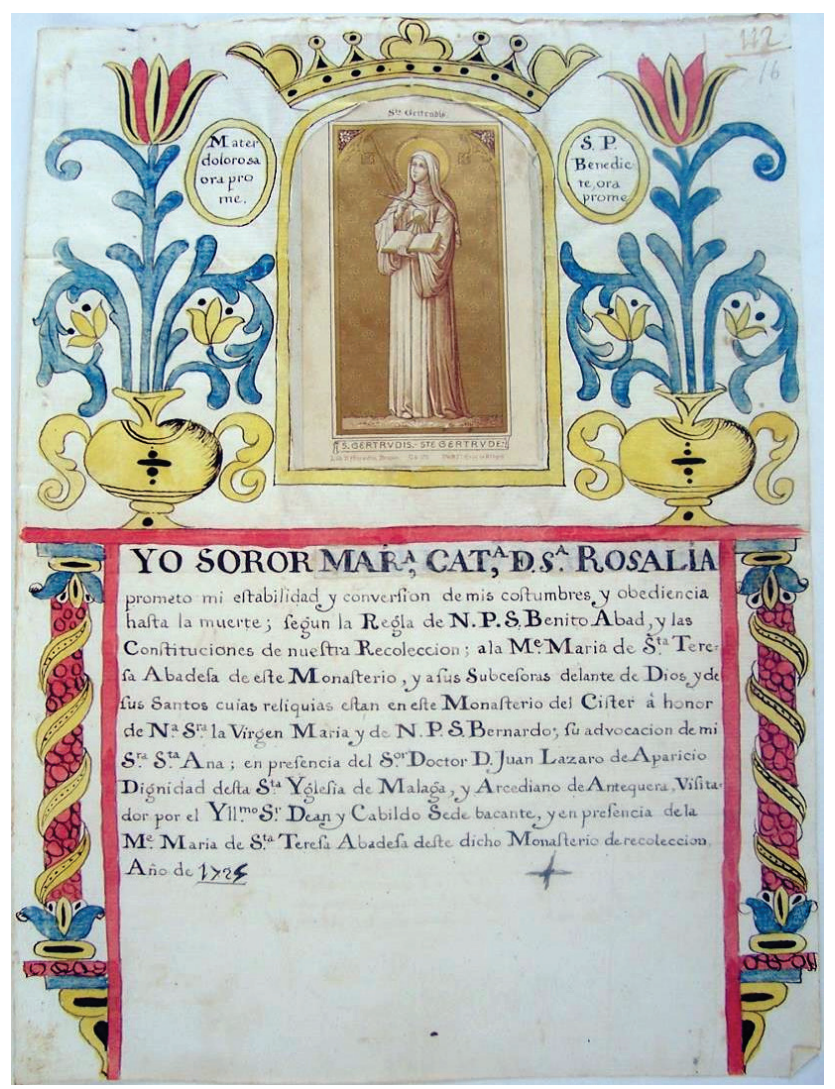

10) Carta de profesión de Sor María Visitación de San Rafael. (16-7-1726; 77). La carta de profesión se decora con un retablo tripartito cuyas imágenes fueron arrancadas del soporte o desaparecieron, al pie de las cuales figuran las leyendas.

Leyendas: 1 "+ Psalmo 115. Veddam tibi vota mea quaedistim rerunt labia"; 2 "+Psalmo131 Hic Regures mea in saeculum seculi"; 3 "+ Vota meo Domino reddam".

Fuente 1: "Ingrediar domum tuam in holocaustis. Reddam tibi vota mea, quae distinxerunt labia mea", Salmos 65: 13-14.

Traducción 1: Vengo a tu casa con holocaustos. Yo te pagaré mis votos, que pronunciaron mis labios.

Fuente 2: "Haec requies mea in saeculum saeculi, hic habitabo quoniam elegi eam", Salmo 131, 14.

Traducción 2: Este es mi reposo por los siglos de los siglos: aquí habitaré, porque la he elegido.

28 J. C. VIZUETE MENDOZA y J. CAMPOS Y FERNÁNDEZ DE SEVILLA, OSA, Iluminaciones..., p. 111.

La profesión religiosa y sus signos, San Lorenzo del Escorial, 2013, p. 9. 
Fuente 3: "Vota mea Domino reddam, in conspectu omnis populi eius", Salmo 115, 14. Traducción 3: Cumpliré mis votos a Jehová, sí, en presencia de todo su pueblo.

Los Salmos están presentes en el desarrollo litúrgico de la misa mayor, contexto en el que se desarrolla la ceremonia de profesión religiosa femenina. Al parecer se trataba de una recolección oficial de cantos usados en la liturgia. Son 150 salmos en total, la mayoría de los cuales contienen un encabezado a modo de título. En los títulos se ofrecen también datos sobre los instrumentos musicales empleados, o de acompañamiento o incluso del uso de melodías conocidas: de cuerda, voces de soprano, tonadas del "no destruyas". Este carácter cantable es lo que posibilita que formen parte activa del ceremonial que rodeó a la profesión religiosa femenina.

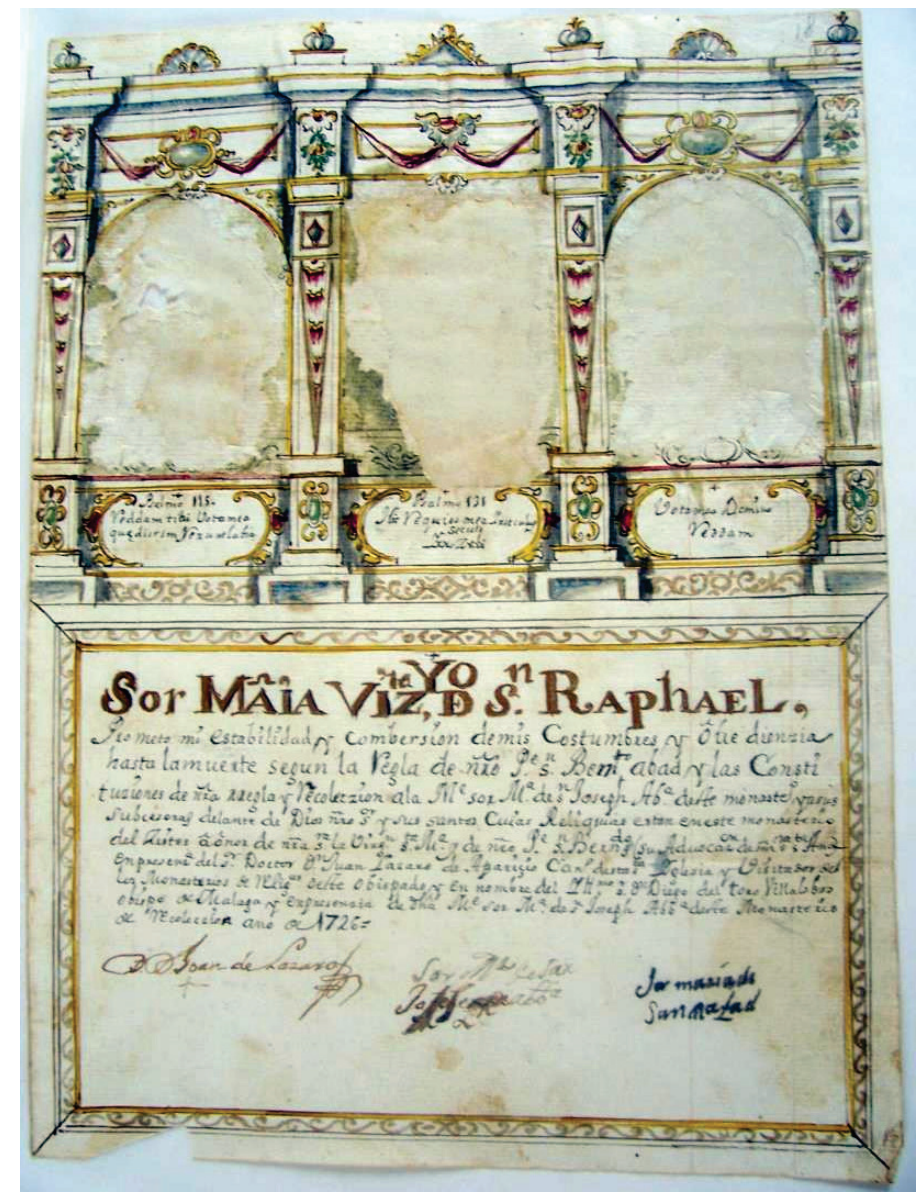

En los tres salmos aludidos en las leyendas latinas de esta carta de profesión se redunda la idea del cumplimiento de votos perpetuos, como corresponde a una profesión religiosa femenina; luego la elección de los textos no es caprichosa, sino que se fundamenta en los preceptos de Reglas y Constituciones de la Comunidad, como ya se ha visto en la carta anterior, número 76 de la serie, con la que está íntimamente relacionada en temática. 
Los textos del libro de los Salmos son citados 1519 veces en la obra de San Bernardo $^{29}$. De hecho, el santo cisterciense copió sin citarlo con frecuencia a Casiodoro en sus comentarios sobre los Salmos. En el seno del rito de la profesión religiosa femenina la novicia, de rodillas ante el visitador o prelado, se establece que pronuncie 3 veces el versículo 116 del salmo 118: "Recíbeme Señor y no me confundas; ni sea en vano mi esperanza (en latín si es monja de velo negro y en castellano si es freila)" 30 .

11) Carta de profesión de Sor Juana de la Cruz (1-4-1731; 83). Imagen de San Juan Bautista con la leyenda en banda que abraza la cruz latina.

Texto leyenda: "Ecce Agnus Dei".

Fuente: Evangelio según San Juan 1,29.

Traducción: He aquí el Cordero de Dios.

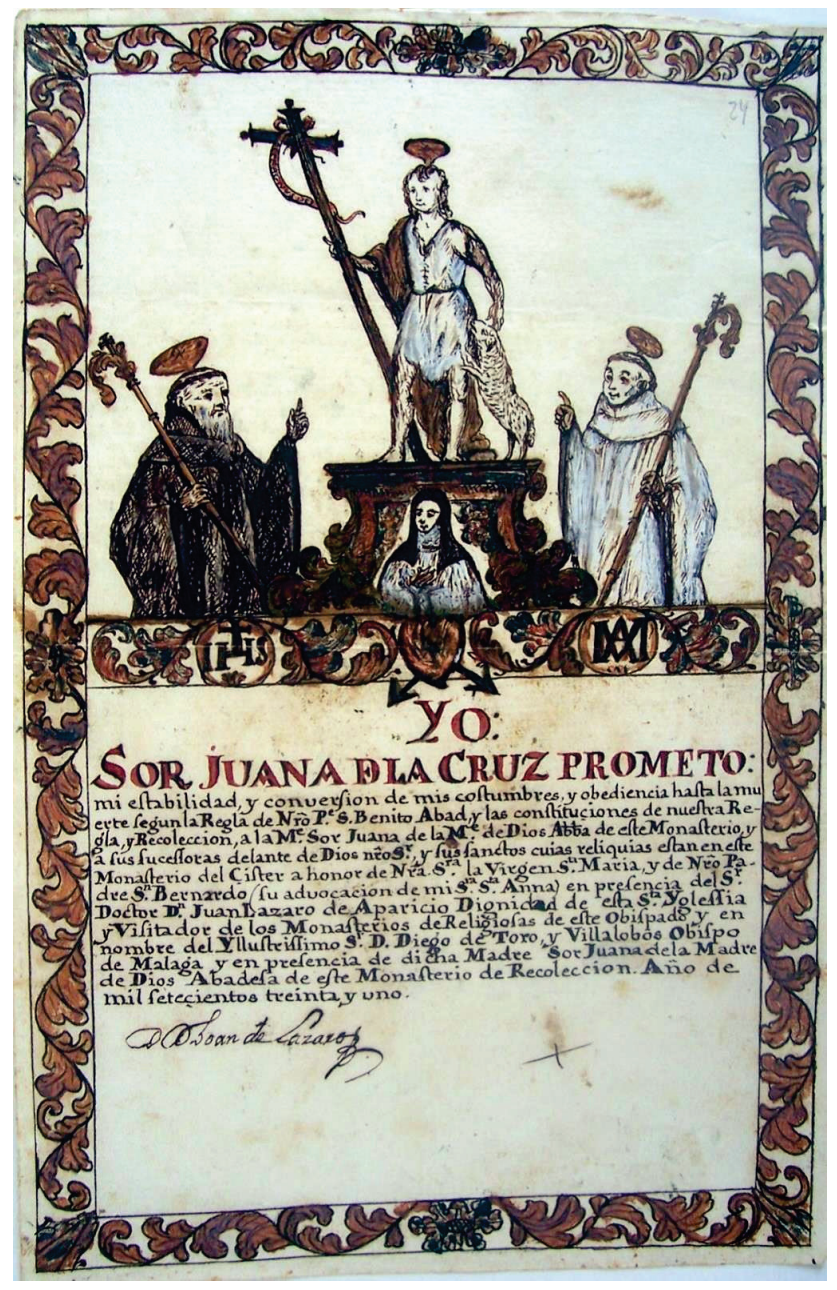

29 G. DÍAZ RAMOS, Obras completas de S. Bernardo, Madrid, 1953, p. 56.

30 Reglas y Constituciones del monasterio de religiosas de la purísima Concepción, Mercedarias descalzas de la villa de Madrid...Madrid, 1766, cap. XLIV, pp. 186-213. 
Los textos de San Agustín de los escritos de San Juan se remontan simbólicamente, como el águila que lo representa, a lo alto de los cielos para derramar desde allí su mensaje sobre el alma de los fieles, y de forma especial sobre los que cultivan intensamente la vida espiritual. San Agustín piensa que San Juan atiende más a las palabras de Jesús que a los hechos, que es donde se fijan más los otros evangelistas, y por eso sus escritos se convierten en doctrina directa, porque es el anuncio personal de Cristo. Sobre esta leyenda se proyecta el Comentario a Jn 1,19-33, predicado en Hipona por San Agustín, en diciembre de 406 ¿domingo 30? ${ }^{31}$ : "Sabéis que algunos hombres dicen a veces: «Nosotros, que somos santos, quitamos a los hombres los pecados, ya que, si no fuese santo el que bautiza, ¿cómo quita el pecado de otro, siendo él hombre lleno de pecado?». Contra estas disputas no digamos palabras nuestras, leamos a éste: He aquí el Cordero de Dios, he aquí el que quita el pecado del mundo. De los hombres no presuman los hombres; no transmigre el pájaro a los montes, confíe en el Señor y, si levanta los ojos a los montes de donde le vendrá el auxilio, entienda que su auxilio viene del Señor, que hizo el cielo y la tierra [...] He aquí el Cordero de Dios, he aquí el que quita el pecado del mundo. Éste es de quien dije: Detrás de mí viene un varón que ha sido hecho antes de mí porque estaba primero que yo. Viene detrás de mí, porque ha nacido después; ha sido hecho antes de mí, porque ha sido preferido a mí; estaba primero que yo, porque En el principio existía la Palabra, y la Palabra existía en Dios, y la Palabra era Dios".

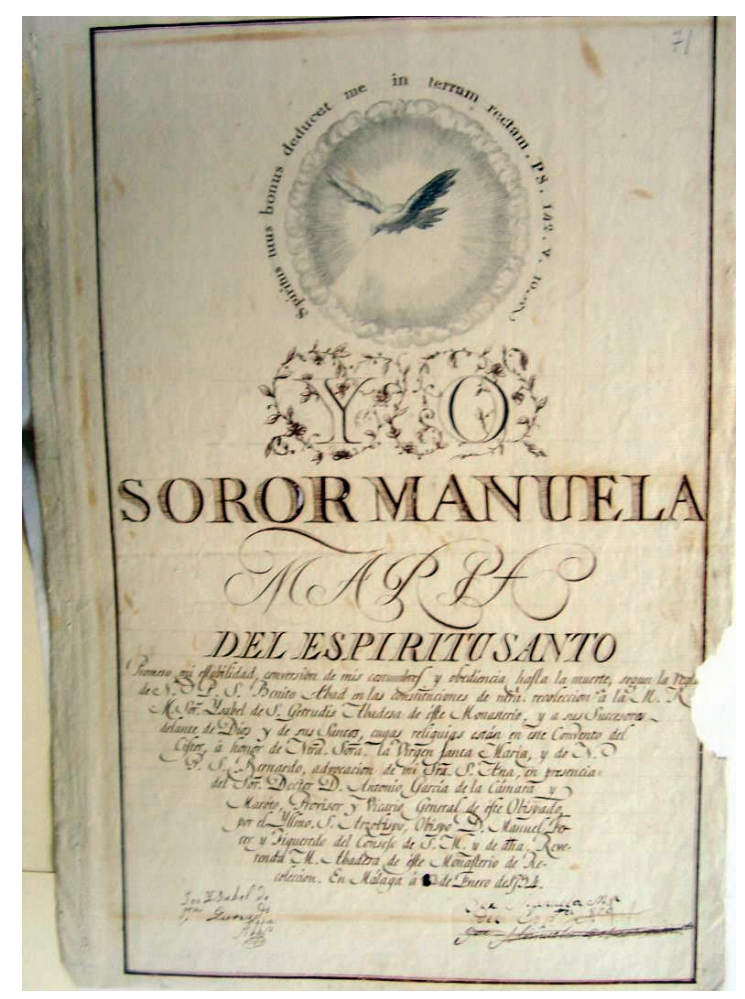

31 M. FUERTES LANERO Y M. M. CAMPELO, Sermones de S. Agustín, Madrid, 1981. 
12) Carta de profesión de Sor Manuela María del Espíritu Santo (12-1-1794; 130). Grabado del Espíritu Santo con forma de paloma con la leyenda: "Spiritus tuus bonus deducet me in terram rectam" P. S. 142. V. 10"

Fuente: Salmos 142:10, "Spiritus tuus bonus deducet me in terram rectam".

Traducción: "Que tu Buen Espíritu me conduzca por una tierra llana".

Al comentario de esta carta se aplicaría todo lo que se ha traído a colación en las cartas anteriores cuyas leyendas habían sido extraídas del Libro de los Salmos.

\section{Conclusiones}

En la serie de cartas de profesión analizadas, las leyendas latinas que beben directamente de los textos bíblicos aluden al libro de los Proverbios (3), Segunda Carta a los Corintios (1), Cantar de los Cantares (2), Salmos (2), Libro del Eclesiástico (1), Evangelio según San Mateo (1) y Evangelio según San Juan (1). Textos muchos de ellos, como se ha venido explicando, directamente relacionados con las preferencias y exégesis de uno de los santos de la orden cisterciense, como fue Bernardo de Claraval. San Bernardo cita 1388 veces en sus escritos las Cartas de San Pablo; 614 veces el Evangelio de San Mateo y 469 veces el Evangelio de San Juan, entre otros ${ }^{32}$. De la tradición del Breviario, rescatan estas cartas malagueñas la antífona del Magnificat "Veni, sponsa Cristi", del Oficio de Laudes del domingo de Adviento, cantada en la ceremonia de profesión mientras que el sacerdote bendecía el velo y el hábito; junto a la Antífona "Hec est virgo sapiens", en alusión al texto bíblico de la Parábola de las vírgenes (Mt 25, 1-13), empleada en el Oficio de la Festividad de Santa Inés, virgen y mártir. En última instancia, se dibuja un tercer grupo de leyendas latinas no relacionadas con los textos ni bíblicos ni del Breviario, nos referimos a las alusiones a los votos monásticos y a las letanías y al rezo del Rosario, componentes litúrgicos más apegados al fenómeno de la promesa y la oralidad que a la tradición de los textos escritos.

Antes de que se generalizara la práctica de inscripción en un libro, bastaba con la cédula en la que la religiosa que profesaba había escrito de su puño y letra, si sabía escribir, el texto de su profesión. Se añadía luego, al pie o al reverso, la fecha, sus datos personales y las suscripciones de los testigos; y aquella cédula o carta, convertida en acta de profesión, era depositada en el archivo. Las cédulas de las monjas, una vez leídas, eran colocadas por el sacerdote sobre el altar ${ }^{33}$. De esta redacción autógrafa dan fe redacciones irregulares de las leyendas latinas, como la que hemos podido constatar en la carta 5 de la serie analizada, profesión de Sor Teresa de Santa Escolástica, en la que los textos latinos aparecen solo sugeridos: "Veni de Libano, veni, Coronaveris de capite..." y "Veni de Libano, sponsa mea" ("Veni de Libano, sponsa, veni de Libano, veni, coronaberis de capite Amana, de vertice Sanir et Hermon, de cubilibus leonum, de montibus pardorum") ; o, como acontece en la carta número 10 de la serie analizada, profesión de Sor María Visitación de San Rafael, en cuyas leyendas aparece un latín desdibujado o incorrecto

G. DÍAZ RAMOS, Obras completas ..., Madrid, 1953, p. 56.

Constituciones para los monasterios de monjas benedictinas de la filiación del Excmo. E Illmo Sr. Arzobispo de Burgos, Burgos, 1844, cap. III, p. 17. 
desde el punto de vista léxico y gramatical : "Veddam tibi vota mea quaedistim rerunt labia" ("Ingrediar domum tuam in holocaustis. Reddam tibi vota mea, quae distinxerunt labia mea"). Señales inequívocas ambas de que las religiosas conocían y sabían estas leyendas y fórmulas latinas, porque las integraban en su vida contemplativa diaria de noviciado, en los rezos litúrgicos de las horas.

Haciendo balance final, podemos concretar que el análisis de estas leyendas latinas presentes en algunas cartas de profesión de la serie completa del archivo cisterciense permite constatar, como ya se ha aludido, que el dominio de la lengua latina era deficiente por parte de algunas religiosas profesas, porque en ocasiones traen a colación solo partes destacadas o intercaladas del texto bíblico completo, en el que insertan deficiencias léxicas y ortográficas que conducen a pensar en la preponderancia de la oralidad en el seno del convento y de la articulación de los rezos.

Por otro lado, si presuponemos, según refieren Reglas y Constituciones, una redacción autógrafa de estas cartas de profesión, como ya se ha apuntado, la redacción de estas leyendas latinas podría contribuir a delatar la formación cultural de la religiosa, elemento que podría contrastarse con su firma y rúbrica en la propia carta o en el Libro de Actas de toma de hábito y profesión, constituyéndose así el texto latino en un elemento más de juicio para determinar el nivel cultural y lectoescriturario de la profesa y por extensión de la mujer en la Edad Moderna.

Las leyendas latinas han permitido fijarnos con más detalle en las representaciones gráficas que acompañan al texto de la profesión, al estar estas íntimamente relacionadas con aquellas. El texto latino potencia, rodea o destaca la imagen o el motivo decorativo central de la carta de profesión. En algunas cartas se han constatado representaciones gráficas de las novicias al profesar, con todos sus atributos, lo que corrobora lo que establecen las Reglas y Constituciones al respecto y que, desde luego, actúa como reflejo de lo que en el Císter malagueño se llevó a cabo.

Partiendo de la base de que el celebrante de la misa mayor donde se incardinaba la profesión podía escoger o sugerir lecturas, según se ha apuntado, ni que decir tiene que los textos bíblicos a los que aluden las leyendas latinas fueron firmes candidatos a protagonizar las lecturas de estas misas mayores, por su conveniencia temática, así como también por ser textos comentados y elogiados por los santos de la orden. Luego los textos latinos de las leyendas no salpican las cartas de profesión aleatoriamente, sino que ofrecen indicios claros sobre los textos bíblicos que protagonizaron el ritual de la profesión religiosa femenina incardinada en el contexto de misa mayor.

De entre estos bíblicos, abundan las referencias a aquellos que desde sus orígenes tuvieron un carácter cantable. El propio libro de los Salmos incluía indicaciones sobe los instrumentos que habían de acompañarlos, y el salmo cantado ha atravesado los siglos en las pautas de celebración litúrgica. Otros textos como la antífona Veni sponsa Cristi los cantaba la comunidad durante el acto de la profesión, e igualmente, las letanías recitadas mientras que la profesa permanecía tendida boca abajo en el suelo del altar, tenían carácter cantable o de cantinela. Se ha visto cómo estos cantos son recordados por las propias religiosas profesas en sus textos de memorias. Lo que redunda en el papel destacado que protagonizó la música en el ceremonial de la profesión religiosa femenina, fenómeno a cuyo redescubrimiento ha contribuido el estudio de las leyendas latinas presentes en las cartas analizadas. 